RESEARCH ARTICLE

\title{
WEED MANAGEMENT PRACTICES TO ENHANCE WEED CONTROL EFFICIENCY IN DIRECT SEEDED RICE (DSR) UNDER SEMI-DRY CONDITIONS.
}

\author{
Sreeja $\mathbf{Y}{ }^{* 1}$, Sakthivel $\mathbf{S}^{1}$, Babu $\mathbf{R}^{\mathbf{2}}$ and Sujatha $\mathbf{K}^{\mathbf{3}}$ \\ ${ }^{1}$ Department of Agronomy, AC\&RI, Tamil Nadu Agricultural University, Madurai - 625104 \\ ${ }^{2}$ Coconut Research Station, Tamil Nadu Agricultural University, Veppankulam - 614906 \\ ${ }^{3}$ Department of Seed Science and Technology, AC\&RI, Tamil Nadu Agricultural University, Madurai - 625104
}

\begin{abstract}
A field experiment was carried out at Agricultural Research Station, Paramakudi, Tamil Nadu during 2017-18 to study the interaction between weed ecology, competition and management strategies in semi-dry Direct Seeded Rice. The field experiment was laid out in split- plot with irrigation in main plot and weed management in sub plot. The results revealed that least weed density was recorded after irrigation when water level droped to $10 \mathrm{~cm}$ below soil surface. Among weed management practices hand weeding twice at 20 and 40 days after sowing (DAS) has recorded the lowest weed density with highest weed control efficiency. Among the interactions, lowest weed density and highest weed control efficiency was recorded when water level droped to $10 \mathrm{~cm}$ below soil surface with combination hand weeding twice at 20 and 40 DAS.
\end{abstract}

Keywords: Weed density ; Weed control efficiency; Hand weeding

\section{INTRODUCTION}

Rice (Oryza sativa. L) is the staple food of India and more than $2 / 3^{\text {rd }}$ population depends on rice and rice derive products for food. It is grown in 43 million hectares with a productivity of 2700 kg.ha-1 (ICARAnnual Report 2020). Traditionally, major growing area is under wetland transplanted ecosystem which requires huge labour for nursery raising, puddling and transplanting operations. But under rainfed ecosystem, direct-sown rice is an alternative to conventional rice for kharif season. Direct seeding of rice offers certain advantages like labour saving by 34 percent (Ho and Romli, 2000), fast and easy establishment less drudgery, early maturity of crop by $7-10$ days, less water requirement to a tune of 12-35\% (Kumar and Ladha, 2011), high tolerance to water deficit, often higher yield, low production cost with a saving of 29 percent (Ho and Romli, 2000) more profit, and also reduced methane emission (Balasubramanian and Hill, 2002).

Weed infestation causes yield loss of around 15 million tonnes in India (Singh et al., 2018) and hence weed management is the major and difficult task in DSR due to the simultaneous emergence of both, crop and weed. Weeds not only compete with crop for space, light, water and nutrients, but also affect its quality. The emergence of weeds along with crop during the initial stages of crop growth causes severe damage, due to high competitive nature of weeds, while the emergence of weeds during later stages is not that much severe. Hence, timely weeding management is indispensable for DSR. Nevertheless, manual weeding is the traditional weeding method- High wages during peak periods, push farmers to seek alternative means of managing weeds in DSR. Hence, chemical weed management by the combination of pre and post emergence herbicides is highly efficient and costeffective method. With an idea to develop a suitable weed management practices in semi-dry DSR, an experiment was devised with the objectives of finding out the best herbicide, dose and time of application of herbicide with irrigation management techniques.

\section{MATERIALS AND METHODS}

\section{Experimental location}

The experimental trail was conducted at Agricultural Research Station, Paramakudi situated at $9^{\circ} 21 \mathrm{~N}$ latitude and $78^{\circ} 22 \mathrm{E}$ longitude with an altitude of 39.83 mean sea level. The place receives a mean annual rainfall of $840 \mathrm{~mm}$ in 43 rainy days, of which $400 \mathrm{~mm}$ is received through Northeast monsoon rains. The monthly mean maximum temperature ranges from $28^{\circ} \mathrm{C}$ to $38.5^{\circ} \mathrm{C}$ and monthly mean minimum temperature ranges from $21^{\circ} \mathrm{C}$ to $27.5^{\circ} \mathrm{C}$. The soil type is clay loam with $\mathrm{pH}$ of 8.0. Experimental field was homogeneously fertile with even topography and uniform textural make up and was attached to the main irrigation 
channel connecting the farm tube well for life saving irrigation. Proper drainage facility was also provided in order to remove excess water during the experimental period.

\section{Experimental material}

Field water tube was used for monitoring the water level drop to ease the process of determining the irrigation timing. The tube was made of 20,25 and $30 \mathrm{~cm}$ long PVC pipe with a diameter of 15 $\mathrm{cm}$, perforated on all sides. The tubes were placed vertically at 10,15 and $20 \mathrm{~cm}$ depth, inside the soil in a flat area of the field close to a bund for easy monitoring of water level drop in the tube.

\section{Experimental design}

The test crop was rice( Anna (R) 4 variety). The weedicides used were pendimethalin (as pre emergence), bispyribac-sodium (as early postemergence), star weeder for manual weeding and hand weeding. The experiment was laid out in splitplot design with eighteen treatment combinations and replicated thrice. Irrigation management consists of three treatments viz., $\mathrm{I}_{1}$ - Irrigation when water level drops to $10 \mathrm{~cm}$ below soil surface, $\mathrm{I}_{2}$. Irrigation when water level drops to $15 \mathrm{~cm}$ below soil surface, $I_{3}$ - Irrigation when water level drops to $20 \mathrm{~cm}$ below soil surface which formed the main plots. In subplots weed management treatments such as $W_{1}$-Pre-emergence pendimethalin @ 1.0 kg.ha-1 at 3 days after sowing (DAS) fo (followed by) one hand weeding at $30 \mathrm{DAS}_{2} \mathrm{~W}_{2}$-early postemergence bispyribac sodium 25 g.ha-1 ${ }^{-1}$ at 15 DAS fb one hand weeding at $30 \mathrm{DAS}, \mathrm{W}_{3}-\mathrm{PE}$ pendimethalin @ 1.0 kg.ha-1 at3DAS fb star weeder at 30DAS, $\mathrm{W}_{4}$ - early post- emergence bispyribac sodium 25 g. ha- ${ }^{-1}$ at 15DAS fb star weeder at 30DAS, $W_{5}$-Preemergence pendimethalin@1.0 kg.ha-1 at 3DAS fb early post-emergence bispyribac sodium@ 25 g.ha-1 at 15 DAS, $_{6}$-hand weeding twice at 20 and 40 DAS-were assigned.

The observations on weed flora, weed density and weed control efficiency of grasses, sedges and broad-leaved weeds were recorded at 15, 30 and 45 DAS. The data on weed density were recorded at $15^{\text {th }}, 30^{\text {th }}$ and $45^{\text {th }}$ day using one square meter quadrant. The quadrant was placed at random locations in each plot and the weeds encompassed within the quadrant were removed from the field, and categorized into grasses, sedges and broadleaved weeds. Then the collected weed samples were shade dried and kept in hot air oven at $65 \pm 5^{\circ} \mathrm{C}$ for $72 \mathrm{hrs}$. to record dry weight of weeds and expressed in $\mathrm{g} \mathrm{ha}^{-1}$.

Weed control efficiency(WCE) was worked out on the basis of weed dry matter recorded in each treatment at 15,30 and 45 DAS by using the formula suggested by Mani et al., (1973).

$107|10-12| 2$

$$
\text { WCE } \%=\frac{W D_{C}-W D_{T}}{W D_{C}} \times 100
$$

Where,

WCE - weed control efficiency (percent)

$W D_{c}$ - weed dry weight $\left(g^{2}\right)$ in unweeded control plot

$W D_{T}$ - weed dry weight $\left(\mathrm{g} \mathrm{m}^{2}\right)$ in the treated plot

\section{Statistical analysis}

The various data generated on weeds were subjected to ANOVA for statistical significance. For statistical analysis of weed density and weed dry weight, the data were subjected to square root transformation $\sqrt{ }(x+0.5)$ before analysis and the critical difference was worked out at five percent probability level.

\section{RESULTS AND DISCUSSION}

\section{Weed flora in the field}

Weed flora of the experimental field during the cropping period primarily comprised of grasses, sedges and broad- leaved weeds. The grass species, Echinochloa colonum; the sedge, Cyperus rotundus and two broad-leaved weeds such as Trianthema protulacastrum and Eclipta alba were dominant in the experimental site. This spectrum of weed flora was earlier reported by many workers (Bhullar et al. 2016 ; Ashraf et al.2018; Singh et al., 2019).

\section{Effect of irrigation and weed management on weed density.}

Weed density was significantly influenced by different treatments and the data on weed density of grasses, sedges and broad-leaved weeds is given in Table1. Further, Irrigation scheduling also had significant influence on grasses, sedges and broad leaved weeds at 15, 30 and 45 DAS. Irrigating when the water level drops to $10 \mathrm{~cm}$ below the soil surface $\left(I_{1}\right)$ significantly recorded the lowest weed density $\left(82.78 \mathrm{~m}^{-2}, 22.08 \mathrm{~m}^{-2}\right.$ and $\left.16.81 \mathrm{~m}^{-2}\right)$. Among treatments at 15DAS, 30 DAS and 45DAS Irrigation when water level drops to $20 \mathrm{~cm}$ below the soil surface $\left(\mathrm{I}_{3}\right)$ recorded higher total weed density $120.50 \mathrm{~m}^{-2}, 30.47 \mathrm{~m}^{-2}$ and $22.35 \mathrm{~m}^{-2}$. The reasons for the low density and dry weight of weeds might be due to the absence of the submerged condition in rice field for longer period and saturated condition would increase the pressure on weeds (Bhagat et al.,1999). Alternate wetting and drying (AWD) method of irrigation treatments recorded high weed density due to continuous germination and competition of weeds with crop for all growth factors (Kabir et al., 2008). 
Table 1. Effect of irrigation and weed management practices on total weed density (Nos. $\mathbf{m}^{-2}$ ) in semi-dry rice during 2017-2018

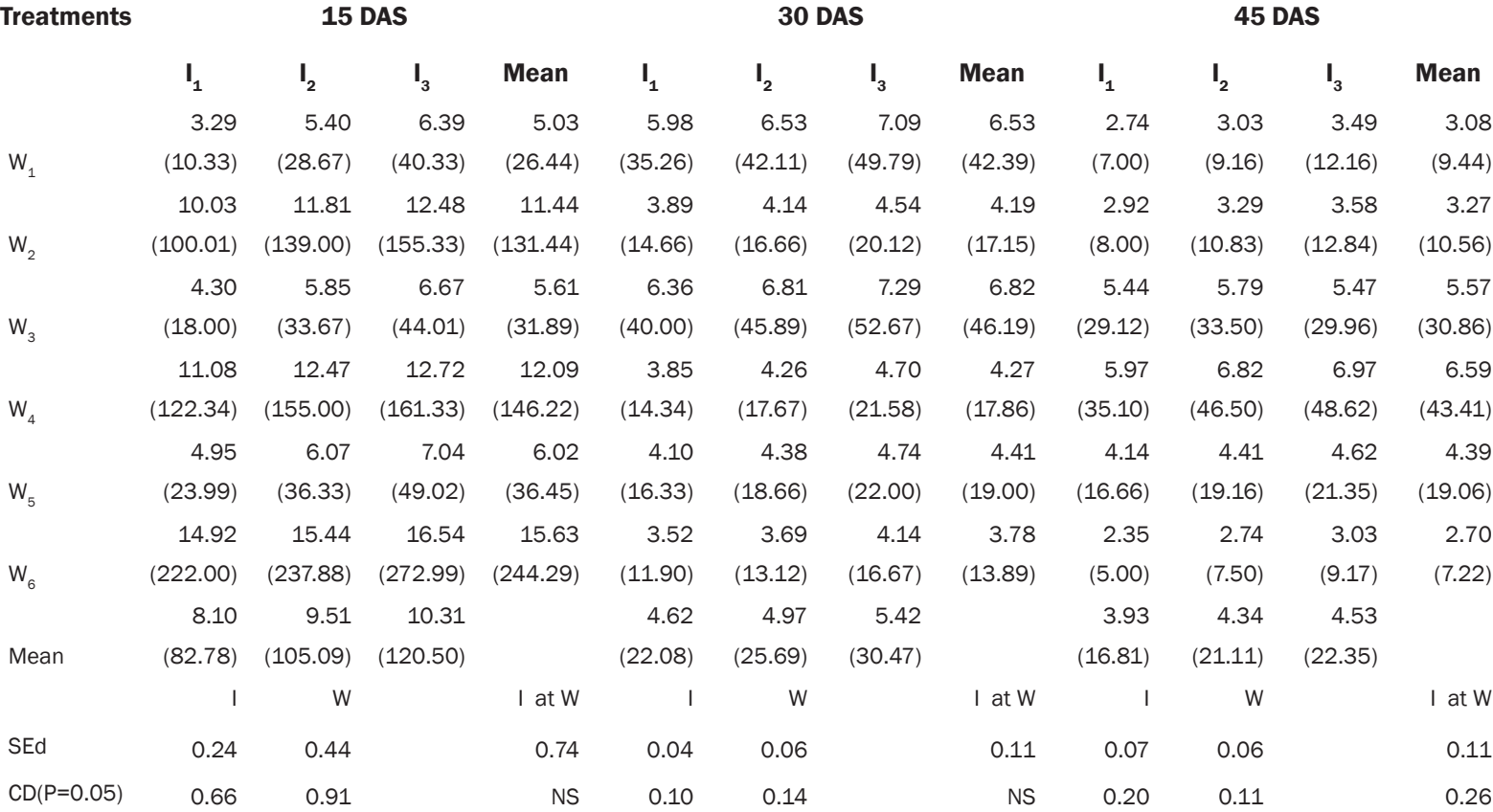

Note: * Figures in parentheses are original value, subjected to square root transformation $(\sqrt{ } x+0.5)$ before statistical analysis.

$\mathrm{I}_{1}$ : Irrigation when water level drops to $10 \mathrm{~cm}$ below the soil surface, $\mathrm{I}_{2}$ : Irrigation when water level drops to $15 \mathrm{~cm}$ below the soil surface, $\mathrm{I}_{3}$ : Irrigation when water level drops to $20 \mathrm{~cm}$ below the soil surface, $\mathrm{W}_{1}$ : PE pendimethalin@ $1.0 \mathrm{~kg}$. ha-1 at 3DAS fb one hand weeding at 30 DAS, $\mathrm{W}_{2}$ : EPOE bispyribac sodium 25 g.ha

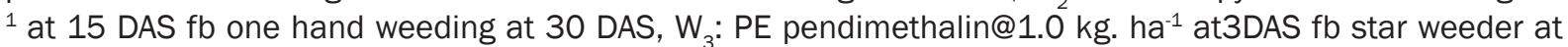
30DAS, $\mathrm{W}_{4}$ : EPOE bispyribac sodium $25 \mathrm{~g} \cdot$ ha $^{-1}$ at 15DAS fb star weeder at 30DAS, $\mathrm{W}_{5}:$ PE pendimethalin@1.0 $\mathrm{kg} \cdot \mathrm{ha}^{-1}$ at 3DAS fb EPOE bispyribac sodium@ $25 \mathrm{~g} \cdot \mathrm{ha}^{-1}$ at $15 \mathrm{DAS}, \mathrm{W}_{6}$ : Hand weeding twice at 20 and 40 DAS.

Among the methods of weed management, chemical management significantly reduced the weed density over the other treatments. Pre-emergence application of herbicide pendimethalin@1.0 kg.ha-1 at 3 days after receipt of sowing rain followed by one hand weeding at 30 days after receipt of sowing rain $\left(W_{1}\right)$ at 15 day recorded significantly lower total weed density $\left(26.44 / \mathrm{m}^{2}\right)$. On 30 day of observation, hand weeding twice at 20 and 40 after receipt of sowing rain followed by early post-emergence application of bispyribac sodium @ 25 g.ha ${ }^{-1}$ at 15 days after receipt of sowing rain $\mathrm{fb}$ one hand weeding at $30 \mathrm{DAS}\left(\mathrm{W}_{2}\right)$ had better control of all types of weeds (grasses, sedges and broad-leaved weeds) and recorded significantly lower total weed density $\left(13.89 \mathrm{~m}^{-2}\right)$. Pre-emergence application of herbicides prevented the emergence of weeds and also controlled the weed growth during earlier stages of rice growth and weeds that emerged at later stages of crop growth were not controlled effectively (Begum et al., 2008). Goswami et al. (2017) It was observed that pendimethalin@1 kg a.i ha-1 $\mathrm{fb}$ bispyribacsodium @ 25 g a.i ha recorded significantly lower total weed density and dry weight than other weed management in direct-seeded rice. Higher total weed density $\left(46.19 \mathrm{~m}^{-2}\right)$ was observed in pre-emergence application of herbicide pendimethalin@1.0 kg.ha${ }^{1}$ at 3 days after receipt of sowing rain followed by star weeder at 30 days after receipt of sowing rain. Hand weeding twice at 20 and 40 days after receipt of sowing rain was effective in weed management due to the complete removal of weeds by hand weeding which ensured weed-free conditions. Next best was pre-emergence application of herbicides pendimethalin which belongs to dinitroaniline group of herbicides that prevents cell division and elongation which in turn inhibits root and shoot growth of grasses and certain broadleaved weeds as reported by Bhullar et al. (2016).Further, bispyribac sodium belongs to pyrimidinyl carboxy group of herbicides which controls diversified weed flora by inhibiting the amino acid bio synthesis and bispyribac sodium lowers the density of certain sedge weeds in the rice ecosystem as observed by Chakraborti et al. (2017).

Irrigation and weed management has profound influence on total weed density at 45 days. Irrigation when the water level drops to $10 \mathrm{~cm}$ below the soil surface $\left(I_{1}\right)$ along with hand weeding twice at 20 and 40 after receipt of sowing rain $\left(\mathrm{I}_{1} \mathrm{~W}_{6}\right)$ recorded lowest 
weed density. This might be due to the removal of weeds by hand weeding in order to maintain the weed free condition. This is in accordance with the finding of Sebastain Micheal et al.(2018).

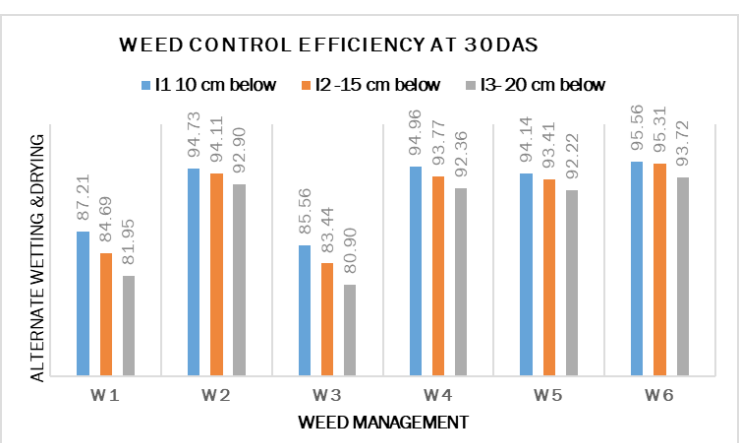

Figure 1: Effect of irrigation and weed management on weed control efficiency at 30 DAS

$\mathrm{W}_{1}$ : PE pendimethalin@ $1.0 \mathrm{~kg} \cdot \mathrm{ha}^{-1}$ at 3DAS fb one hand weeding at $30 \mathrm{DAS}, \mathrm{W}_{2}$ : EPOE bispyribac sodium 25 g.ha- $^{-1}$ at 15 DAS fb one hand weeding at 30 DAS, $W_{3}$ : PE pendimethalin@1.0 kg. ha ${ }^{-1}$ at3DAS $\mathrm{fb}$ star weeder at 30DAS, $\mathrm{W}_{4}$ : EPOE bispyribac sodium 25 g. ha $^{-1}$ at 15DAS fb star weeder at 30DAS, $\mathrm{W}_{5}$ :PE pendimethalin@1.0 kg.ha-1 at 3DAS fb EPOE bispyribac sodium@ $25 \mathrm{~g} \cdot$ ha $^{-1}$ at 15DAS, $\mathrm{W}_{6}$ : Hand weeding twice at 20 and 40 DAS.

\section{Weed control efficiency (WCE \%)}

Hand weeding twice at 20 and 40 days after receipt of sowing rain $\left(W_{6}\right)$ had proved their effectiveness in weed control with higher WCE of $94.86 \%$. While lower WCE (83.30\%) was recorded on the application of herbicide pre-emergence pendimethalin @1.0 kg. ha-1 at 3 days after receipt of sowing rain $\mathrm{fb}$ star weeder at 30days after receipt of sowing rain.

The efficiency of treatment on the control of weed in terms of dry weight is given in Fig1. The higher weed control efficiency (92.02\%) on Irrigation was recorded when water level droped to $10 \mathrm{~cm}$ below the soil surface $\left(I_{1}\right)$. These results attributed to reduced weed population, weed dry weight of different weed flora and resulted in increased weed control efficiency. Irrigation when water level drops to at $20 \mathrm{~cm}$ below soil surface $\left(\mathrm{I}_{3}\right)$ recorded lower weed control efficiency (89.01\%).

The Interaction was significant and the treatment $\left(I_{1}\right)$ irrigation when the water level drops to $10 \mathrm{~cm}$ below the soil surface with hand weeding twice at 20 and 40 days after receipt of sowing rain $\left(\mathrm{I}_{1} \mathrm{~W}_{6}\right)$ recorded the maximum WCE $(95.56 \%)$. The minimum $(80.90 \%)$ was found in irrigation when water level drops to at $20 \mathrm{~cm}$ below soil surface with pre-emergence application of pendimethalin @ $1.0 \mathrm{~kg}^{\mathrm{h} \mathrm{h}^{-1}}$ at 3 DAS fb star weeder at 30days after receipt of sowing rain.

\section{CONCLUSION}

Hand weeding twice at 20 and 40 days after receipt of sowing rain to be highly effective in controlling the weeds due to complete removal of weed at the critical stage under semi-dry direct seeded rice.

\section{REFERENCES}

Ashraf, U.H., Sher, S. A., Abrar, M., Khan, I. and S.A. Anjum. 2018. Planting geometry and herbicides for weed control in rice. implications and challenges. In Grasses as Food and Feed., Intech Open.

Balasubramanian, V and Hill, J.K. 2002. Direct seeding of rice in Asia: emerging issues and strategic research needs for the 21st century. 25-28 Jan. 2000, Bangkok, Thailand. Los Banos (Philippines). International Rice Research Institute. 15-39.

Begum, M., Juraimi, A., Rajan, A. and S. Omar. 2008. Critical period competition between Fimbristylismiliacea (L.) Vahl and rice (MR 220). Plant Protection., 23(4) : 153

Bhagat, R. M., Bhuiyan, S. I., Moody, K. and L.E. Estorninos.1999. Effect of water, tillage and herbicide on ecology of weed communities in intensive wet-seeded rice ecosystem. Crop Prot.,18 : 293-303

Bhullar, M.S., Kumar,S., Kaur, S., Kaur,T., Singh,J., Yadav, R and G. Gill . 2016. Management of complex weed flora in dry-seeded rice. Crop Protection., $83: 20-26$.

Chakraborti, M., Duary, B. and M. Datta. 2017. Effect of Weed Management Practices on Nutrient Uptake by Direct Seeded Upland Rice under Tripura Condition. Int. J Curr. Microbiol. App. Sci., 6(12) : 66-72.

Goswami, G., Singh, Y. and S. Kumar. 2017. Effect of Agronomic Practices and Weed Management Practices on Weed Dry Weight and Weed Control Efficiency in Direct Seeded Rice under Rainfed Condition of Eastern Uttar Pradesh, India. Int. J. Curr. Microbiol. App. Sci., 2132-2138

Ho, N and Z. Romli. 2000.Impact of direct seeding on rice cultivation. lesions from the Muda area of Malaysia. In: Proceedings of workshop on direct seeding: Research strategies and opportunities held during 25-28th January 2000 at Bangkok, Thailand, ICAR - National Rice Research Institute: Annual report 2020.

Kabir, M.H., Bari, M.N., Haque, M.M., Ahmed, G.J.U. and A.J.M.S. Islam. 2008. Effect of water management and weed control treatments on the performance of transplanted aman rice. Bangladesh $\mathrm{J}$. of Agricultural Res.,33(3) : 399-408.

Kumar, V. and J.K. Ladha.2011. Direct seeded of rice. Recent developments and future research needs. Advances in Agronomy., 111 : 299-413.

Mani, V.S., Malla, M.L., Gautam, K.C. and Bhagwndas. 1973. Weed killing chemicals in potato cultivation. Indian Farm., VXXII : 17-18.

Sebastain Micheal, J.S.A., Juraimi,A.S., Selamat,A., Man, A.,Anwar,P. and M.K.Uddin.2013. Critical

$107 \mid 10-12$ | 4 
period of weedcontrol in aerobic rice system. Australian J.of Cro Sci.,7(5) : 665.

Singh., Animesh., Singh, Y., Singh, R., Upadhyay, P.K., Kumar, R. and R.K.Singh . 2019. Effect of cultivars and weed management practices on weeds, productivity and profitability in zero-till direct-seeded rice (Oryza sativa).Indian J. of Agri Sci., 89 (2) : 353-359.

Singh, P., Shrivasatava G.K., Verma, A.K. and I. Singh . 2018. Effect of different doses of herbicides and mechanical weeding on yield attributes and grain yield of direct seeded rice (Oryza sativa L.) varieties under Inceptisols of Chhattisgarh plain. International J. of Chem Stu.,6(1) : 1929-193. Singh, P.,

Shrivasatava G.K., Verma, A.K. and I. Singh . 2018. Effect of different doses of herbicides and mechanical weeding on yield attributes and grain yield of direct seeded rice (Oryza sativa L.) varieties under Inceptisols of Chhattisgarh plain. International J. of Chem Stu.,6(1):1929-193. 